\title{
Reconstruction of Diadema mexicanum bioerosion impact on three Costa Rican Pacific coral reefs
}

\author{
Juan José Alvarado ${ }^{1,2}$, Jorge Cortés ${ }^{1,3}$ \& Héctor Reyes-Bonilla ${ }^{4}$ \\ 1. Centro de Investigación en Ciencias del Mar y Limnología (CIMAR), Universidad de Costa Rica, San Pedro, 11501- \\ 2060 San José, Costa Rica; juanalva76@yahoo.com; jorge.cortes@ucr.ac.cr \\ 2. Posgrado en Ciencias Marinas y Costeras, Universidad Autónoma de Baja California Sur, La Paz, México. \\ 3. Escuela de Biología, Universidad de Costa Rica. \\ 4. Departamento de Biología Marina, Universidad Autónoma de Baja California Sur, La Paz, México; hreyes@uabcs.mx
}

Received 23-II-2011. C Corrected 05-X-2011. Accepted 29-II-2012.

\begin{abstract}
Absctract: The 1982-83 El Niño event produced a high coral mortality (50-90\%) in several localities in the Eastern Tropical Pacific, which resulted in an outbreak of the sea urchin populations of Diadema mexicanum A. Agassiz, 1863 in some reefs, leading to an increase in coral framework bioerosion. In Costa Rica, El Niño impact varied among three of the most important coral reefs localities, being higher in Cocos Island, moderate in Caño Island, and lower in Culebra Bay; D. mexicanum densities followed the same pattern. To understand the historic role of this sea urchin on the balance between bioerosion and bioacretion, we made a reconstruction of bioerosion impact based on current patterns of carbonate ingestion by the sea urchins, growth rates and skeletal density of the main coral builders, and historical information of sea urchin population density and coral cover. The reconstruction model varied depending on locality. At Cocos Island, the effect on the reef carbonate budget ranged from negative to positive, improving coral recruitment and the recovery of the reef. At Caño Island, there was no apparent effect. In Culebra Bay, the effects ranged from a positive-neutral effect to a negative one, the latter possibly associated with an increase of eutrophic conditions that facilitated bioerosion of the coral framework. The importance of this sea urchin in reef dynamics varies with amount of reef protection, overfishing, and coastal management, and it has a large influence on the carbonate balances of the Pacific Costa Rican coral reefs. Rev. Biol. Trop. 60 (Suppl. 2): 121-132. Epub 2012 April 01.
\end{abstract}

Keywords: Density, coral cover, bioerosion, bioacretion, management, reef budget, Eastern Tropical Pacific.

Eastern Tropical Pacific (ETP) reefs are thin $\mathrm{CaCO}_{3}$ accumulations in relation to their counterparts from the Indo-Pacific and Caribbean (Cortés 1997, Manzello et al. 2008). Most are relative small (1-2 ha), discontinuous, limited to shallow depths $(10 \mathrm{~m})$, built by few species, ephemeral in geological time (with low rates of carbonate production but fairly rapid framework accumulation), low cemetation, and have complex food webs (Glynn 1977, Glynn \& Macintyre 1977, Macintyre et al. 1992, Cortés et al. 1994, Cortés 1997, Glynn 2004, 2008, Manzello et al. 2008). Two main types of reef structures can be observed in the region (Cortés
1997, 2003): reefs in Mexico, Panama, Colombia and some areas in Costa Rica and Ecuador are built by species of the genus Pocillopora. The other type of reef consists of Porites lobata or Pavona clavus massive corals, with the best developed being at Cocos, Clipperton and Galapagos islands.

The Eastern Tropical Pacific has been one of the most affected regions by sea warming as a result of El Niño events (Glynn \& Colley 2001), with significant live coral cover losses at most localities (50-100\%) due to bleaching (Glynn 1988,1990, 1996, Guzman \& Cortés 1992, 2001, 2007, Glynn et al. 2001, Jiménez 
\& Cortés 2001, Jiménez et al. 2001, Baker et al. 2008), which facilitated the growth of macroalgae and increased bioerosion by sea urchins (Glynn et al. 1979, 1988, 1997, Eakin 1992, 1996, 2001, Reaka-Kudla et al. 1996, Guzman \& Cortés 1992, 2007). During the 1982-83 El Niño event in Costa Rica, a high coral mortality (90\%) was observed at Cocos Island (Guzman \& Cortés 1992), 50\% mortality at Caño Island (Guzman et al. 1987), and death of coral colonies of Pocillopora spp. was observed in Culebra Bay (Cortés et al. 1984). During the 1997-98 El Niño event, the coral reefs of these three localities were less impacted ( $5 \%$ coral mortality) than other ETP reefs (Guzman \& Cortés 2001, Jiménez et al. 2001), despite the fact that this El Niño was considered to be the most intense one of the last century (Enfield 2001).

After the 1982-83 El Niño event in Cocos Island, Guzman and Cortés (1992) predicted that coral recovery was going to take centuries due to the high densities of bioeroders and the low coral reproduction rates. Guzman and Cortés $(1992,2007)$ indicated that part of the deterioration of the reef structures on Cocos island was due to the bioerosive action of Diadema mexicanum A. Agassiz, 1863. In 2002, there was a five-fold increased of coral cover and a notable reduction in sea urchins. Guzman \& Cortés (2007), determined that D. mexicanum was not playing a relevant role in the reef bioerosion. However, the urchin still could fulfill its key role in assisting the recruitment of corals, as has been observed in other reefs in the Caribbean (Sammarco et al. 1974, Sammarco 1980, 1982a, b, Mumby et al. 2006).

We reconstruct the behavior of the bioerosion and bioacretion rates on the reef at Cocos and Caño islands and from Culebra Bay from 1980 until 2009, using published and field information of coral cover, growth and skeletal density, as well as population densities and daily carbonates ingestions of $D$. mexicanum. Our goal was to understand the role that $D$. mexicanum plays in the balance of reef growth and destruction through time

\section{MATERIALS AND METHODS}

To reconstruct a reef budget it was necessary to estimated the current bioacretion and bioerosion rates. For this, we visited three reef sites per study area (Fig. 1), where transects to measure coral cover and sea urchin density were deployed. Three field studies were done in 2009: 1) 1-5 March, Cocos Island

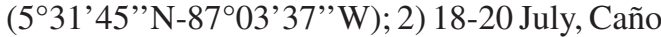
Island ( $8^{\circ} 41^{\prime} 36$ ' $\left.\mathrm{N}-83^{\circ} 52^{\prime} 05^{\prime \prime} \mathrm{W}\right)$; and 3) 29-31

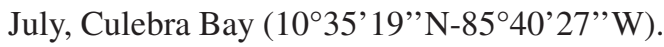

Three $10 \mathrm{~m}$ long and $1 \mathrm{~m}$ wide transects were deployed parallel to the coast, between 4 and $8 \mathrm{~m}$ deep. A $1 \mathrm{~m}^{2}$ quadrat, divided into $0.01 \mathrm{~m}^{2}$ cells was placed every meter, on the right side of the transect line (Weinberg 1981). The amount of live, dead, and bleached coral cover, and also macroalgae, crustose coralline algae, rocks and sand cover were determined for each quadrat. In addition, sea urchin $(D$. mexicanum) abundances were counted along the $20 \mathrm{~m}^{2}$ belt transect.

To determine the bioerosion rate per locality (removal of $\mathrm{CaCO}_{3}$ per time unit), 30 sea

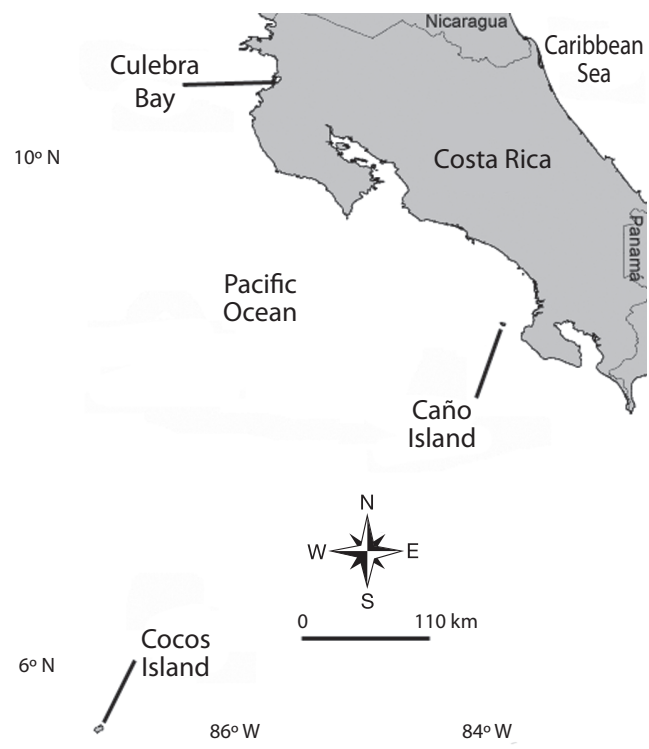

Fig. 1. Study areas: Culebra Bay, Caño Island, Cocos Island.

Fig. 1. Áreas de estudio: Bahía Culebra, Isla del Caño, Isla del Coco. 
urchins were collected (between 08:00 and 10:00 hours) and placed in plastic buckets (5 1), leaving them to evacuated the gut content for a period of 24 hours (Glynn 1988, Reyes-Bonilla \& Calderón-Aguilera 1999). The evacuated material was collected and later dried in an oven at $60^{\circ} \mathrm{C}$ for $24 \mathrm{~h}$. The samples were weighted on an analytic balance $(0.0001 \mathrm{~g})$ and transferred to a furnace at $500^{\circ} \mathrm{C}$ for $6 \mathrm{~h}$. After this period, the samples (ashes) were measured again. The difference between the weights determined the amount of organic matter that is present in the sea urchin's gut (Carreiro-Silva \& McClanahan 2001). The remaining portion represents the inorganic fraction, composed by $\mathrm{CaCO}_{3}$ and non-soluble residues (silica fragments like quartz grains, sponge spicules, diatoms, radiolarians and lime). Inorganic fractions were digested with $10 \% \mathrm{HCl}$. The remaining material, after dissolution of the carbonates, was filtered with a pre-weighed fiberglass filter. The weight of the residue material retained on the filter corresponds with the non-carbonate fraction (NCF). The difference between the ashes and the weight of the residue equals the $\mathrm{CaCO}_{3}$ (Carreiro-Silva \& McClanahan 2001). This gives us the amount of carbonates removed by each sea urchin $\left(\mathrm{CaCO}_{3} \mathrm{~g}_{\text {ind }}^{-1} \mathrm{~d}^{-1}\right)$.

The bioerosion rates per urchin $\left(\mathrm{kg} \mathrm{m}^{-2}\right.$ $\left.\mathrm{y}^{-1}\right)$ at the different study areas were calculated by multiplying the daily carbonate content $\left(\mathrm{CaCO}_{3} \mathrm{~g}\right.$ ind $\left.^{-1} \mathrm{~d}^{-1}\right)$ by density of the sea urchins (ind $\mathrm{m}^{-2}$ ) over 365 days (modified from Carreiro-Silva \& McClanahan 2001).

To obtain the carbonate deposition rate of the coral, we used the method proposed by Chave et al. (1972), which combines the coral growth rate $\left(\mathrm{cm} \mathrm{y}^{-1}\right)$ and the coral skeletal density $\left(\mathrm{g} \mathrm{cm}^{-3}\right)$ to calculate the gross carbonate production. We multiplied this result by the amount of live coral cover (LCC) to estimate the net deposition of carbonates on the reef $\left(\mathrm{CaCO}_{3} \mathrm{~kg} \mathrm{~m}^{-2} \mathrm{y}^{-1}\right)$.

To obtain the skeletal and coral growth rates, we sampled 10 fragments of colonies of Porites lobata from Cocos Island, five of $P$. lobata from Caño Island, five of Pocillopora elegans from Caño Island, and five of P. elegans from Culebra Bay. The samples were sent to the laboratory of Ecología Marina, Centro de Investigación Científica y Educación Superior de Ensenada (CICESE), Baja California, México, where the Carricart-Gavinet and Barnes (2007) protocol was applied to obtain density values. The values for coral growth were taken from the literature (Guzman \& Cortés 1989, Jiménez \& Cortés 2003). For Cocos Island, 10 colonies were stained with Alizarin Red (Lamberts 1978) in August 2007, removed in September 2008, then sliced, measured and the growth rate calculated.

To reconstruct the carbonate budgets, we assumed that coral growth and skeletal density were the same for all the analyzed years, as well as the carbonate content present in the sea urchin's guts. Coral growth can varied between years or seasons, so our reconstruction assumed an "ideal scenario" to asses only the impact of D. mexicanum on reef accretion. To determine the past bioerosion rates, we used literature information about historical $D$. mexicanum densities (Guzman 1986, Guzman \& Cortés 1992, 2007, Lessios et al. 1996, Jiménez 1998, Alvarado \& Chiriboga 2008, J.J. Alvarado unpubl. data) and present densities. In addition, to determine past bioacretion rates, we used historical live coral cover information (Guzman et al. 1987, Guzman \& Cortés 1992, 2007, Jiménez 2001, J.J. Alvarado \& J. Cortés unpubl. data), and present covers. The carbonate balance is a quantitative measured of the functional state of the reef (Perry et al. 2008). As used here, balance refers to the net carbonate budget change in each reef system by comparing the production and the erosion. It is positive if the reef is growing and negative if the reef is eroding (Eakin 2001).

Finally, we analyzed the relationship between $D$. mexicanum density and the results of reef balance with a logarithmic regression. The regression equation was used to calculate possible scenarios of reef balance in Culebra Bay at different urchin densities (3, 4, 5 and 11 ind $\mathrm{m}^{-2}$ ). 


\section{RESULTS}

Table 1 displays: 1) carbonate amounts present in the D. mexicanum's gut, and 2) coral growth and skeletal density for the main reefbuilder species. The highest amount of carbonate present in the urchin guts was at Cocos Island, and lowest at Caño Island (Table 1). Pocillopora elegans possesses a higher growth rate than Porites lobata (Table 1). Coral skeletal density was similar in the three study areas, being higher at the species level for $P$. lobata than for P. elegans (Table 1).

At Cocos Island, we observed a reduction of D. mexicaum density from 1987 to 2009 , and a gradual increase in live coral cover (Table 2, Fig. 2A). At this island, the highest sea urchin densities were reported $\left(11.4\right.$ ind $\left.\mathrm{m}^{-2}\right)$ in 1987 ,

TABLE 1

Values used to calculate the bioerosion, bioacretion and reef balance models.

Pe: Pocillopora elegans; Pl: Porites lobata

\section{CUADRO 1}

Valores utilizados para calcular los modelos de bioerosión, bioacreción y balance arrecifal.

Pe: Pocillopora elegans; Pl: Porites lobata

\begin{tabular}{lcccc} 
Study area & $\begin{array}{c}\mathrm{CaCO}_{3} \text { evacuated by } \\
\text { the urchin } \\
\left(\mathrm{CaCO}_{3} \mathrm{~g} \mathrm{ind}^{-1}\right)\end{array}$ & $\begin{array}{c}\text { Growth rate } \\
\left(\mathrm{cm} \mathrm{y}^{-1}\right)\end{array}$ & $\begin{array}{c}\text { Skeletal density } \\
\left(\mathrm{g} \mathrm{cm}^{-3}\right)\end{array}$ & Source \\
Cocos Island & 2.25 & $1.16(\mathrm{Pl})$ & $1.26(\mathrm{Pl})$ & This study \\
Caño Island & 0.56 & $3.33(\mathrm{Pe}) 1.34(\mathrm{Pl})$ & $1.19(\mathrm{Pe}) 1.32(\mathrm{Pl})$ & $\begin{array}{c}\text { Guzman \& Cortés 1989, this study } \\
\text { Culebra Bay }\end{array}$ \\
\hline
\end{tabular}

TABLE 2

Sea urchin D. mexicanum density and live coral cover used to build the bioerosion, bioacretion and reef balance models

CUADRO 2

Densidad del erizo de mar D. mexicanum y de cobertura de coral vivo utilizados para construir los modelos de bioerosión, bioacreación y balance arrecifal

\begin{tabular}{|c|c|c|c|}
\hline Year & $\begin{array}{l}\text { Density D. mexicanum } \\
\quad \text { (ind } \mathrm{m}^{-2} \text { ) }\end{array}$ & $\begin{array}{l}\text { Live coral cover } \\
(\%)\end{array}$ & Source \\
\hline \multicolumn{4}{|c|}{ Cocos Island } \\
\hline 1987 & 11.4 & 3.0 & Guzman \& Cortés 1992 \\
\hline 1990 & 6.1 & 3.0 & Guzman \& Cortés 1992, Lessios et al. 1996 \\
\hline 2002 & 0.84 & 23.0 & Guzman \& Cortés 2007 \\
\hline 2006 & 1.06 & 24.0 & Alvarado \& Chiriboga 2008, J. Cortés unpublished data \\
\hline 2009 & 0.45 & 24.0 & This study \\
\hline \multicolumn{4}{|c|}{ Caño Island } \\
\hline 1980 & 0.27 & 17.8 & Guzman et al. 1987 \\
\hline 1984 & 0.46 & 8.6 & Guzman 1986, Guzman et al. 1987 \\
\hline 2007 & 0.09 & 26.6 & J.J. Alvarado unpublished data \\
\hline 2009 & 0.28 & 38.0 & This study \\
\hline \multicolumn{4}{|c|}{ Culebra Bay } \\
\hline 1996 & 0.20 & 53.4 & Jiménez 1998, 2001 \\
\hline 2006 & 0.23 & 38.5 & J.J. Alvarado unpublished data \\
\hline 2009 & 2.19 & 2.5 & This study \\
\hline
\end{tabular}




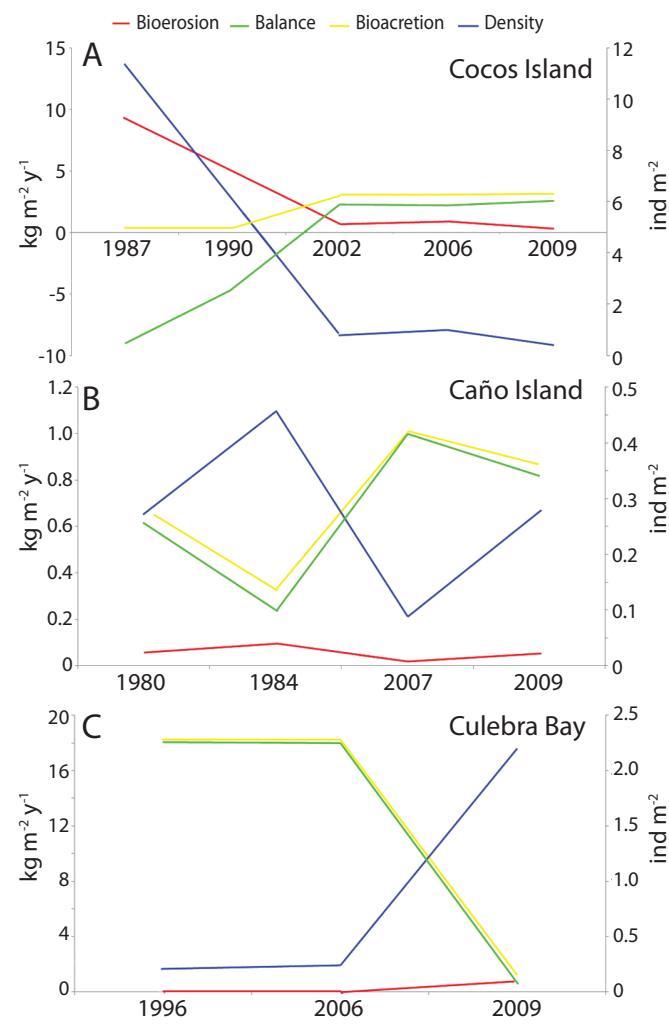

Fig. 2. Historical behavior of the density (ind $\mathrm{m}^{-2}$ ) and bioerosion $\left(\mathrm{kg} \mathrm{m}^{-2} \mathrm{y}^{-1}\right)$ of the sea urchin Diadema mexicanum, coral bioacretion $\left(\mathrm{kg} \mathrm{m}^{-2} \mathrm{y}^{-1}\right)$ and reef balance in A) Cocos Island, B) Caño Island, and C) Culebra Bay, Costa Rica.

Fig. 2. Comportamiento histórico de la densidad (ind $\mathrm{m}^{-2}$ ) y bioerosión $\left(\mathrm{kg} \mathrm{m}^{-2} \mathrm{año}^{-1}\right)$ del erizo de mar Diadema mexicanum, bioacreción coralina $\left(\mathrm{kg} \mathrm{m}^{-2}\right.$ año-1) y el balance arrecifal en A) la Isla del Coco, B) la Isla del Caño, y C) Bahía Culebra, Costa Rica.

whereas they were $\leq 1$ ind $\mathrm{m}^{-2}$ (Table 2) from 2002 to 2009. At Caño Island, the densities were below 0.50 ind $\mathrm{m}^{-2}$, while in Culebra Bay they increased $900 \%$ from 2006 to 2009 (Table 2). In the three study areas, live coral cover was high $(\sim 20-50 \%)$ during times when urchin densities were low $\left(<1\right.$ ind $\mathrm{m}^{-2}$, except for Caño in 1984), and low ( 3\%) when the densities of D. mexicanum were close to 3 ind $\mathrm{m}^{-2}$ (Table 2). From the three study areas, Caño Island maintained a relatively constant coral cover and urchin density, except that coral cover decreased in 1984, with a slight increase in D. mexicanum density (Table 2 ).

In Cocos Island, as the density of Diade$m a$ decreased, its bioerosion impact decreased (Fig. 2A). In 1987, intense bioerosion $(9.3 \mathrm{~kg}$ $\left.\mathrm{m}^{-2} \mathrm{y}^{-1}\right)$ and very low bioacretion $\left(0.4 \mathrm{~kg} \mathrm{~m}^{-2}\right.$ $\mathrm{y}^{-1}$ ) were observed, resulting in a negative balance in the carbonate budget (Fig. 2A). At this locality there was a positive balance in 2002, which was maintained until 2009, with net accretion of $3.1 \mathrm{~kg} \mathrm{~m}^{-2} \mathrm{y}^{-1}$ (Fig. 2A).

In Caño Island, D. mexicanum had little impact on bioerosion $\left(<1 \mathrm{~kg} \mathrm{~m}^{-2} \mathrm{y}^{-1}\right)$ in comparison to Cocos Island (Fig. 2A-B). Also, bioacretion has been high $\left(\sim 11 \mathrm{~kg} \mathrm{~m}^{-2} \mathrm{y}^{-1}\right)$, producing a positive carbonate balance (Fig. 2B).

Finally, in Culebra Bay the carbonate balance was highly positive, with bioacretion rates of $18 \mathrm{~kg} \mathrm{~m}^{-2} \mathrm{y}^{-1}$ and low bioerosion rates $\left(0.07 \mathrm{~kg} \mathrm{~m}^{-2} \mathrm{y}^{-1}\right)$ until 2006. After that date, there was a drastic change in the carbonate budget, becoming almost negative by 2009 (0.43 kg m $\mathrm{kg}^{-2} \mathrm{y}^{-1}$; Fig. 2C). The bioerosion rate increased from 0.07 to $0.75 \mathrm{~kg} \mathrm{~m}^{-2} \mathrm{y}^{-1}$, as a result of the increase in sea urchin density (Fig. 2C). Loss of coral cover (Table 2) resulted from the proliferations of harmful phytoplankton that caused high mortality in the area (Jiménez 2007, Jiménez et al. in prep).

The relationship between $D$. mexicanum density and reef carbonate balance is negative (Fig. 3). When there are few sea urchins, carbonate balance is highly positive (Culebra Bay: 1996 and 2006). When the density of sea urchins exceeds $\sim 1.5$ ind $\mathrm{m}^{-2}$, reef balance start to be negative, becoming highly erosive when urchin density exceeds 4 ind $\mathrm{m}^{-2}$. Figure 3 help to explain how quickly can be a negative process, such as in Culebra Bay, where in less than 3 years there was a fast loss on reef balance. Also, this analysis help to visualized the slow process of recovery took Cocos Island after a strong disturbance until now days. In the case of Caño Island, it seems that D. mexicanum does not possess a key role in reef balance. For Culebra Bay, a continuing increase in sea urchin density will produce a negative balance. 


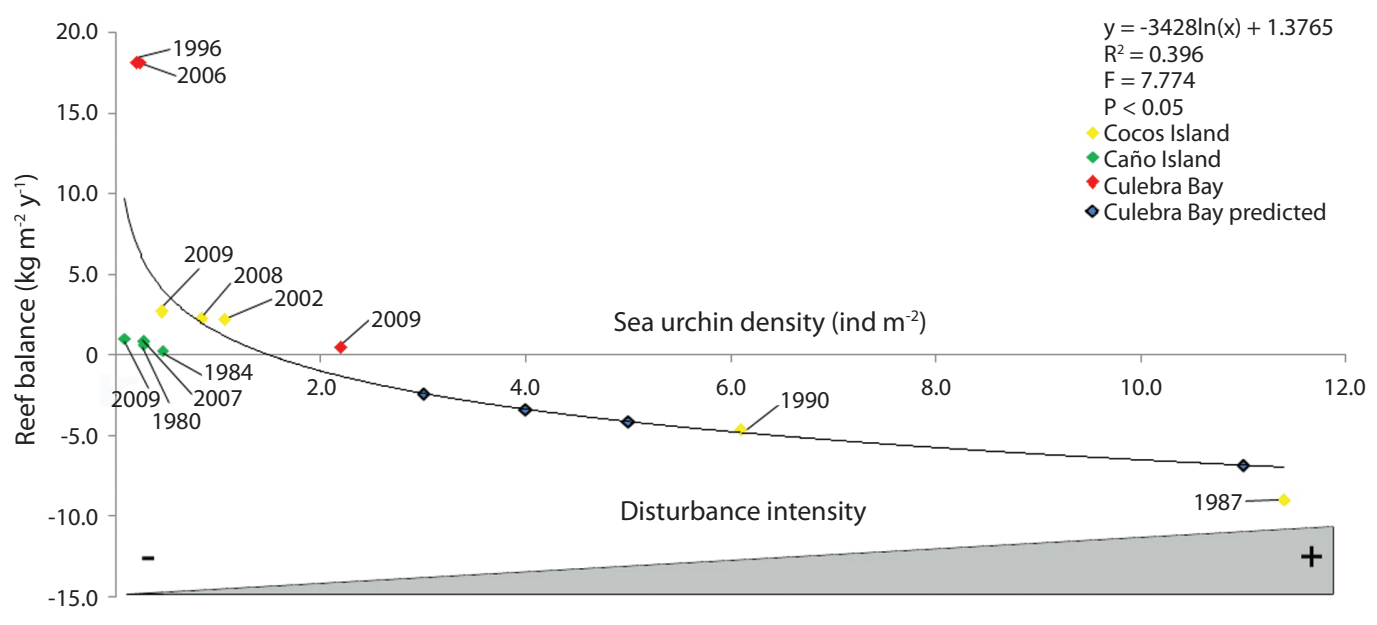

Fig. 3. Logarithmic relationship between Diadema mexicanum density (ind $\left.\mathrm{m}^{-2}\right)$ and the reef balance $\left(\mathrm{kg} \mathrm{m}^{-2} \mathrm{y}^{-1}\right)$, indicating predicted scenarios of negative reef balance for Culebra Bay if the disturbance intensities continues with densities of 3, 4 and 11 urchins $\mathrm{m}^{-2}$. The years indicated on the figure correspond with the sampling dates of each study area.

Fig. 3. Relación logarítmica entre la densidad de Diadema mexicanum (ind $\left.\mathrm{m}^{-2}\right)$ y el balance arrecifal $\left(\mathrm{kg} \mathrm{m}^{-2} \mathrm{y}^{-1}\right.$ ), indicando predicciones de escenarios de balance arrecifal negativo para Bahía Culebra si la intensidad de los disturbios continúan con densidades de 3, 4 y 11 erizos $\mathrm{m}^{-2}$. Los años indicados en la figura corresponden con las fechas de muestreo de cada área de estudio.

The 2009 densities were 2.19 ind $\mathrm{m}^{-2}$, pushing the reefs near negative balance. An increase to 3 ind $\mathrm{m}^{-2}$ would produce a considerable reduction on reef erosion, and an increase to 11 ind $\mathrm{m}^{-2}$ would produce a similar impact to reef balance as the one seen in Cocos Island after the 1982-1983 El Niño event.

\section{DISCUSSION}

Guzman and Cortés (2001) observed that after severe disturbance, the recovery of ETP reefs has been slow, due to the lack of recruitment and the continuous predation by corallivorous organisms. In the case of the 1982-83 El Niño, the recovery was limited by 1) the extreme oceanographic conditions of the region, 2) the high coral mortality suffered during the El Niño, 3) the intense herbivory resulting from high sea urchin concentrations produced high rates of bieorosion, 4) low abundance of recruits due to reduced sexual activity of the main reef builder species, and 5) low potential for successful recruitment due to the low abundance of crustose coralline algae (Guzman \& Cortés 2001). Baker et al. (2008) indicated that, for a reef affected by bleaching to recover, a change in the balance between reef accumulation and erosion, the ability to maintain healthy levels of herbivory, and macroalgae cover and coral recruitment are required.

After the 1982-83 El Niño, there was a high incidence of coral mortality and bleaching at Cocos Island. During this period there were high sea urchin densities (Guzman \& Cortés 1992), producing a negative carbonate budget, and reef erosion in 1987. It took approximately 15 years for those reefs to switch back to a positive balance. Probably, as Guzman and Cortés (2007) indicated, the impact of the sea urchin as bioeroder declined, and its action as a herbivore facilitated coral recruitment. Thus, the role of the sea urchin can change in accordance with its density.

Glynn et al. (2009) indicated a similar recovery pattern for the coral reefs at Darwin 
Island, northern Galapagos Archipelago, which underwent lower bioerosion in comparison with other reefs in the Archipelago (Glynn 1988). This resulted in an intact reef framework and, together with successful sexual and asexual coral recruitment (Glynn et al. 2009), there was a similar recovery as observed at Cocos Island.

The recovery in reef balance observed at Cocos Island, like at Darwin Island, could be due in part to the positive role that Diadema can have through creating spaces for settlement (Carleton \& Sammarco 1987) and increasing the cover of crustose coralline algae, which enhances successful settlement (Morse et al. 1988). Vance (1979) found that the sea urchin Centrostephanus coronatus, a member of the Diadematidae family, avoids consuming crustose coralline algae when eating other algae, favoring development of coralline algae. Nevertheless, the sea urchin in search of its food can erode the substrate simply by scraping areas where algae grow (Toro-Farmer 1998). Therefore, in the case of Cocos Island, the herbivorous activity of $D$. mexicanum possibly resulted in a larger abundance of calcareous algae, and a greater availability of substrate for recruitment of new coral recruits, favoring its recovery.

Eakin (2001) indicated that the reef budget in Uva Island, Panama, between 1985 and 2000, was negative, without showing signs of recovery. In some places the densities of Diadema diminished due to the reduction in the reef complexity due to the urchin's erosion, diminishing their refuge. In Cocos Island, reef complexity has remained high (Alvarado et al. in prep.), but density of sea urchins has diminished (Fig. 2A, Table 2), which is probably related to predation. This island has been a no-take Marine Protected Area for the last 30 years, and protection has been strictly enforced for the last 10 years. This has favored the recovery of trophic webs. This contrasts with Panama, where the reefs were under strong fishing pressure for many years, diminishing the presence of predators on D. mexicanum. It has been observed that inside marine reserves, where the fishing pressure has been reduced, the trophic interactions are re-established between the sea urchins and their predators (McClanahan et al. 1999), as opposed to places where intense fishing is occurring and densities of Diadema are high (Harborne et al. 2009).

At Caño Island, from the historic densities of D. mexicanum (Fonseca 1999, Guzman \& Cortés 2001, Fonseca et al. 2006), it seems that this sea urchin has not been an important bioeroder and that its impact has been minimum (Fig. 2B). Scott et al. (1988) indicated that after the 1982-83 El Niño, this island experienced intense bioerosion $\left(9 \mathrm{~kg} \mathrm{~m}^{-2} \mathrm{y}^{-1}\right)$. Later, in 1996, Fonseca (1999) determined a lower bioerosion rate $\left(0.05 \mathrm{~kg} \mathrm{~m}^{-2} \mathrm{y}^{-1}\right)$ for Platanillo Reef, as well as high bioacretion $(7.1 \mathrm{~kg}$ $\left.\mathrm{m}^{-2} \mathrm{y}^{-1}\right)$. Guzman and Cortés (2001) indicated that these reefs in the 1997-98 El Niño had less effect than prior events because of high crustose coralline cover (80-95\%) and successful coral recruitment.

In Culebra Bay, bioerosion increased after 2009, when a massive explosion of D. mexicanum occurred. The reefs from this area underwent intense mortality due to recurrent proliferations of phytoplankton between 2006 and 2009; these produced intense bleaching resulting from the anoxic conditions of the water and the lack of sun light penetrating to the bottom (Jiménez et al. en prep.). Dead corals were replaced by turf algae. This availability of algae could have caused an increase in the recruitment of sea urchins, increasing their densities, and their bioerosional effect. If this bioerosion continues, the coral framework will be weakened and may collapse (Colgan \& Glynn 1990). Figure 4 illustrates the difference in conditions in 2005 compared to now.

Bioerosion intensity depends on several environmental factors, like depth, light and nutrient supply (Chazottes et al. 1995). Baker et al. (2008) indicated that a variety of disturbances can cause a significant reduction in live coral cover. Eutrophication, sedimentation and bleaching can quickly initiate to an erosive phase, resulting in a loss of structural integrity and topographical relief. Moreover, Edinger et al. (2000) mentioned that coral reefs growing 

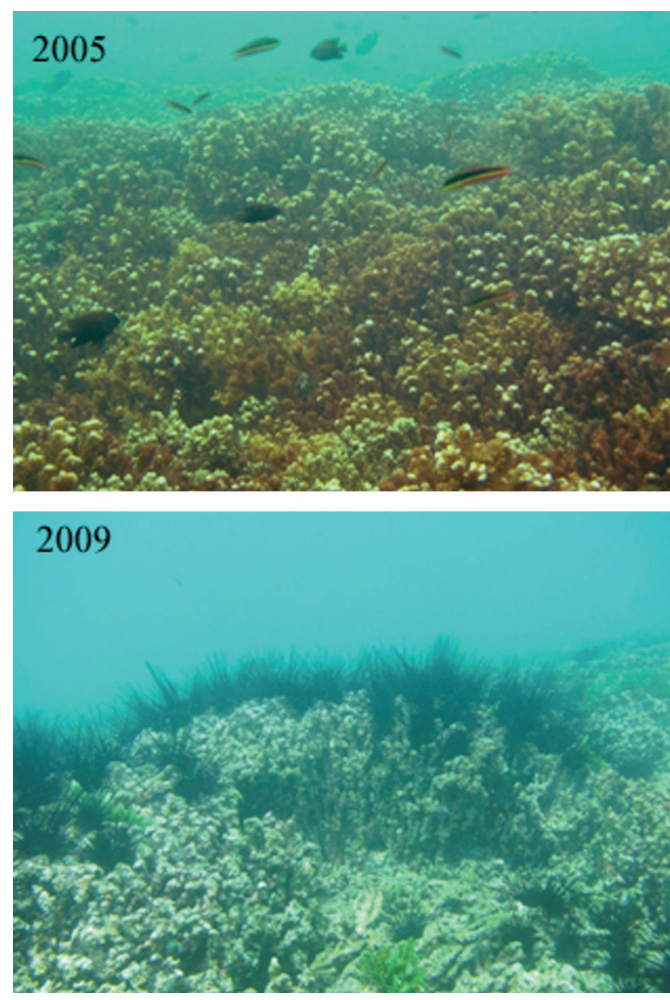

Fig. 4. Change on the substrate composition on Playa Blanca reef, Culebra Bay, between 2005 and 2009.

Fig. 4. Cambio en la composición del sustrato en el arrecife de Playa Blanca, Bahía Culebra entre el 2005 y el 2009.

in eutrophic coastal environments are exposed to higher bioerosion than those in clear oceanic waters, resulting in negative carbonate budgets. In Dominican Republic, Tewfik et al. (2005) found that a nutrient enrichment together with overfishing accelerated the environment deterioration, and facilitated an increase in sea urchin densities (Lytechinus variegatus). As consequence of this population increase there was a considerable reduction on the diversity on the affected areas.

In Culebra Bay, the environmental conditions have deteriorated in recent years due to anthropogenic eutrophication (Fernández 2007, Fernández et al. in prep.). This has resulted in invasions by Caulerpa sertularoides (Fernández \& Cortés 2005, Fernández 2007) and phytoplankton proliferations (Jiménez 2007,
Jiménez et al. in prep.). As a consequence, live coral cover in the Bay has declined (Jiménez 2007, Bezy et al. 2006, Cortés et al. 2010, Fernández et al. in prep.). When nutrients become abundant, reef carbonate producers tend to be overgrown by fast-growing fleshy and filamentous algae. Meanwhile the bioeroders tend to increase due to the food availability, magnifying the negative effects (Chazottes et al. 1995). Additionally, successful recruitment by juvenile sea urchins have been attributed to algal proliferation because of the increase in nutrient availability, favoring a greater density of sea urchins in organically enriched areas (Eklöf et al. 2008).

Another negative factor that could have promoted an increase in D. mexicaunm high densities at Culebra Bay, is that this area suffers from a strong fishing pressure, with few controls and complete lack of protection of the resources. With few or no sea urchin predators and with more food available, Diadema reached densities never before reported for the area (Table 2), causing an increase in bioerosion of the coral framework. On Marías Island in Mexico, and in the Canary, Galapagos and Hawai'i archipelagos, it has been observed that reductions in the populations of predator fishes by overfishing resulted in an increase in sea urchin abundance (Torrejón-Arellano et al. 2008, Clemente et al. 2009, Sonnenholzner et al. 2009, Vermeij et al. 2010).

According to Muthiga and McClanahan (2007) it is of interest to record the historical level of the Diadema populations, as it may indicate the degree to which the sea urchin are required for the maintenance of the coral reef ecology or a negative factor that has been released from predation by overfishing. Through the reconstructions presented here (Fig. 2), it is possible to visualize how Diadema mexicanum can have either a positive or a negative effect on coral reef development in the Eastern Tropical Pacific. Moreover, it was shown that for the sea urchin to have a positive or negative role, a series of synergies are required to switch it in one direction or another. Bad coastal management (anthropogenic eutropfication) 
and overfishing (lack of sea urchin predators), can result in this sea urchin eroding the coral framework, as seen in Culebra Bay. However, where the trophic webs are "healthy", Diadema mexicanum facilitates the growth of crustose coralline algae, which at the same time helps the recovery of coral cover. As Veron et al. (2009) pointed out, "a reef far from additional human stress can realize a rapid recovery, returning to its own diversity in less than a decade". Cocos Island, is an example of this statement, while Culebra Bay, being subjected to additional stress, likely will take longer to recover. MPAs provide the means for effectively limiting the number of urchins on coral reefs and subsequently returning the calcium carbonate cycle to a more balanced state (Brown-Saracino et al. 2007). However, if the anthropogenic eutrophied conditions diminish, there is fishery management, and there is stronger protection of the reef environments, it is possible that Diadema can help in the recovery of those reefs. To assess the future development of reef structures and their relationship with sea urchins it is important to continue monitoring the populations on all of these reefs. However, it is currently extremely important to do this in Culebra Bay, so that management measures can be initiated if $D$. mexicanum attain densities of $>3$ ind $\mathrm{m}^{-2}$. Also, it is extremely important to begin studying recruitment and reproduction patterns, as well as to initiate efficient coastal and fishery management practices. Glynn and Fong (2006) stated that if corals survive total mortality and if environmental conditions return to pre-disturbance levels, there exits the potential for rapid coral recovery in a few years. For Culebra Bay, this statement is extremely important, because its highlight the need for a better coastal management that would improve coastal ecosystems and their services.

\section{ACKNOWLEGMENTS}

We acknowledge the following persons and institutions that collaborate during the development of this work: C. Fernández, O. Breedy, C. Sánchez, S. Martínez, E. Gómez,
A. Planas, V. Flores, O. Norzagaray, L.E. Calderón-Aguilera, Centro de Investigación en Ciencias del Mar y Limnología (CIMAR, Universidad de Costa Rica), Universidad Autónoma de Baja California Sur (UABCS), Reserva Biológica Isla del Caño and Parque Nacional Isla del Coco park-rangers, MY Adventure crew, Instituto Costarricense de Turismo, Hotel Punta Marenco Lodge, Águila de Osa Inn, Centro de Investigación Científica y Educación Superior de Ensenada (CICESE). A special acknowledgement for their economic support of this research: Vicerrectoría de Investigación of the Universidad de Costa Rica, Ministerio de Ciencia y Tecnología de Costa Rica (MICIT), Consejo Nacional para Investigaciones Científicas y Tecnológicas de Costa Rica (CONICIT), Consejo Nacional de Ciencia y Tecnología de México (CONACYT), Fonds Français pour l'Environnement Mondial (FFEM) and Ecodesarrollo Papagayo. We appreciated the comments made by four anonymous reviewers that enrich this paper.

\section{RESUMEN}

El fenómeno de El Niño de 1982-83 produjo una alta mortalidad coralina (50-90\%) en varias localidades del Pacífico Tropical Oriental, lo que en algunos arrecifes trajo como consecuencia una explosión en la poblaciones de erizos de mar, Diadema mexicanum, y por consiguiente un aumento en la bioerosión del basamento coralino. En Costa Rica, el impacto fue diferencial en tres localidades arrecifales, siendo mayor en la Isla del Coco, intermedio en la Isla del Caño, y menor en Bahía Culebra, con similares patrones en la presencia del erizo D. mexicanum. Con el fin de poder entender el papel histórico que desempeña este erizo de mar en el balance entre bioerosión y bioacreción, se reconstruyó el impacto bioerosivo basándose en patrones actuales de ingestión de carbonatos por parte del erizo, tasas de crecimiento y densidad del esqueleto coralino, y datos históricos de densidad poblacional del erizo y cobertura coralina. Los resultados de las reconstrucciones variaron dependiendo de la localidad. En la Isla del Coco, el efecto de los erizos de mar varío de un efecto negativo sobre el balance arrecifal de carbonatos a un efecto positivo, favoreciendo el reclutamiento coralino y la recuperación del arrecife. En la Isla del Caño, Diadema presentó un efecto neutro, al no tener una participación preponderante en el balance de carbonatos de esta isla. Mientras, que en Bahía Culebra, los efectos de los erizos de mar pasaron de tener un efecto positivo-neutro, a uno 
negativo, posiblemente asociado a un incremento en condiciones eutróficas de la bahía que están favoreciendo un incremento en la bioerosión del basamento coralino. El valor de este erizo en la dinámica arrecifal y su relación con la protección, sobrepesca, y manejo costero, posee una gran influencia en el balance de carbonatos en los arrecifes coralinos del Pacífico de Costa Rica.

Palabras claves: Densidad, cobertura coralina, bioerosión, bioacreción, manejo, balance arrecifal, Pacífico Tropical Oriental.

\section{REFERENCES}

Alvarado, J.J. \& A. Chiriboga. 2008. Distribución y abundancia de equinodermos en las aguas someras de la Isla del Coco, Costa Rica (Pacífico Oriental). Rev. Biol. Trop. 56 (Supl. 2): 99-111.

Baker, A.C., P.W. Glynn \& B. Riegl. 2008. Climate change and coral reef bleaching: An ecological assessment of long-term impacts, recovery trends and future outlook. Estuar. Coast. Shelf Sci. 80: 435-471.

Bezy, M.B., C. Jiménez, J. Cortés, A. Segura, A. León, J.J. Alvarado, C. Gillén \& E. Mejía. 2006. Contrasting Psammocora-dominated coral communities in Costa Rica, tropical eastern Pacific. Proc. 10 ${ }^{\text {th }}$ Int. Coral Reef Symp., Okinawa: 376-381.

Brown-Saracino, J., P. Peckol, H.A. Curran \& M.L. Robbart. 2007. Spatial variation in sea urchins, fish predators, and bioerosión rates on coral reefs of Belize. Rev. Biol. Trop. 26: 71-78.

Carleton, J.H. \& P.W. Sammarco. 1987. Effects of substratum irregularity on success of coral settlement: quantification by comparative geomorphological techniques. Bull. Mar. Sci. 40: 85-98.

Carreiro-Silva, M. \& T.R. McClanahan. 2001. Echinoid bioerosion and herbivory on Kenyan coral reefs: the role of protection from fishing. J. Exp. Mar. Biol. Ecol. 262: 133-153.

Carricart-Gavinet, J.P. \& D.J. Barnes. 2007. Densitometry from digitized images of X radiographs: Methodology for measurement of coral skeletal density. J. Exp. Mar. Biol. Ecol. 344: 67-72.

Chave, K.E., S.V. Smith \& K.J. Roy. 1972. Carbonate production by coral reefs. Mar. Geol. 12: 123-140.

Chazottes, V., T. Le Campion-Alsumard \& M. Peyrot-Clausade. 1995. Bioerosion rates on coral reefs: interactions between macroborers, microborers and grazers (Moorea, French Polynesia). PALAEO 113: 189-198.
Clemente, S., J.C. Hernández \& A. Brito. 2009. Evidence of the top-down role of predators in structuring sublittoral rocky-reef communities in a Marine Protected Area and nearby areas of the Canary Islands. ICES J. Mar. Sci. 66: 64-71.

Colgan, M. 1990. El Niño and the history of Eastern Pacific reef building, p. 183-232. In: P.W. Glynn (ed.). Global Ecological Consequences of the 1982-83 El Niño-Southern Oscillation. Elsevier Oceanographic Series, Netherlands.

Cortés, J. 1997. Biology and geology of eastern Pacific coral reefs. Coral Reefs 16 (Suppl.): S39-S46.

Cortés, J. 2003. Coral reefs of the Americas: An introduction to Latin American Coral Reefs, p. 1-7. In J. Cortés (ed.). Latin American Coral Reefs. Elsevier, Amsterdam.

Cortés, J., M.M. Murillo, H.M. Guzman \& J. Acuña. 1984. Pérdida de zooxantelas y muerte de corales y otros organismos arrecifales en el Caribe y Pacífico de Costa Rica. Rev. Biol. Trop. 32: 227-231.

Cortés, J., C.E. Jiménez, A.C. Fonseca \& J.J. Alvarado. 2010. Status and conservation of coral reefs in Costa Rica. Rev. Biol. Trop. 58 (Suppl. 1): 33-50.

Eakin, CM. 1992. Post-El Niño Panamanian reefs: less accretion, more erosion and damselfish protection. Proc. $7^{\text {th }}$ Int. Coral Reef Symp., Guam 1: 387-396.

Eakin, C.M. 1996. Where have all the carbonates gone? A model comparison of calcium carbonate budgets before and after the 1982-1983 El Niño at Uva Island in the eastern Pacific. Coral Reefs 15: 109-119.

Eakin, C.M. 2001. A tale of two events: carbonate budgets and the influence of two warming disturbances and intervening variability, Uva Island, Panama. Bull. Mar. Sci. 69: 171-186.

Edinger, E.N., G.V. Limmon, J. Jompa, W. Widjatmokos, J.M. Heikoop \& M.J. Risk. 2000. Normal coral growth rates on dying reefs: are coral growth rates good indicators of reef health? Mar. Poll. Bull. 40: 404-425.

Eklöf, J.S., M. de la Torrre-Castro, M. Gullström, J. Uku, N. Muthinga, T. Lyimo \& S.O. Bandeira. 2008. Sea urchin overgrrazing of seagrasses: a review of current knowledge on causes, consequences, and management. Estuar. Coast. Shelf Sci. 79: 559-580.

Enfield, D.B. 2001. Evolution and historical perspective of the 1997-1998 El Niño-Southern Oscillation event. Bull. Mar. Sci. 69: 7-25. 
Fernández, C. 2007. Propagación del alga Caulerpa sertularoides en Bahía Culebra, Golfo de Papagayo, Pacífico norte de Costa Rica. Tesis de maestría, Universidad de Costa Rica, San José, Costa Rica. 92 p.

Fernández, C. \& J. Cortés. 2005. Caulerpa sertularioides, a green alga spreading aggressively over coral reef communities in Culebra Bay, North Pacific of Costa Rica. Coral Reefs 24: 10 .

Fonseca, A.C. 1999. Bioerosión y bioacreción en arrecifes coralinos del Pacífico sur de Costa Rica. M.Sc. Thesis, Universidad de Costa Rica, San José, Costa Rica. 206 p.

Fonseca, A.C., H.K. Dean \& J. Cortés. 2006. Non-colonial coral macroborers as indicators of coral reef stress in the south Pacific of Costa Rica. Rev. Biol. Trop. 54: 101-115.

Glynn, P.W. 1977. Coral growth in upwelling and nonupwelling areas off the Pacific coast of Panama. J. Mar. Res. 35:567-585.

Glynn, P.W. 1988. El Niño warming, coral mortality and reef framework destruction by echinoid bioerosion in the eastern Pacific. Galaxea 7: 129-160.

Glynn, P.W. 1990. Coral mortality and disturbances to coral reefs in the tropical eastern Pacific, p. 55-126. In: P.W. Glynn (ed.). Global Ecological Consequences of the 1982-83 El Niño-Southern Oscillation. Elsevier Oceanographic Series, Netherlands.

Glynn, P.W. 1996. Coral reef bleaching: facts, hypotheses and implications. Glob. Change Biol. 2: 495-509.

Glynn, P.W. 1997. Bioerosion and coral-reef growth: a dynamic balance, p. 68-95. In C. Birkeland (ed.) Life and Death of Coral Reefs. Chapman \& Hall, New York.

Glynn, P.W. 2004. High complexity food webs in lowdiversity Eastern Pacific reef-coral communities. Ecosystems 7: 358-367.

Glynn, P.W. 2008. Food-web structurestructure and dynamics of Eastern Tropical Pacific coral reefs: Panamá and Galápagos, p. 185-208. In: T.R. McClanahan \& G.M. Branch (eds.). Food Webs and the Dynamics of Marine Reefs. Oxford University Press, Oxford.

Glynn, P.W., \& I.G. Macintyre 1977. 1977. Growth rate and age of coral reefs on the Pacific coast of Panama. Proc $3^{\text {th }}$ Int. Coral Reef Symp., Miami 2: 251-259.

Glynn, P.W. \& S.B. Colley (Eds.). 2001. A collection on the effects of the 1997-98 El Niño-Southern Oscillation events on corals and corals reefs in the eastern tropical Pacific. Bull. Mar. Sci. 69: 288 p.

Glynn, P.W. \& P. Fong. 2006. Patterns of reef coral recovery by the regrowth of surviving tissues following the 1997-98 El Niño warming and 200, 2001 upwelling cool events in Panamá, Eastern Pacific. Proc. $10^{\text {th }}$ Int. Coral Reef Symp., Okinawa: 624-630.

Glynn P.W., G.M. Wellington, \& C. Birkeland. 1979. Coral reef growth in the Galápagos: limitation by sea urchins. Science 203: 47-49.

Glynn, P.W., J.L. Maté, A.C. Baker, \& M.O. Calderon. 2001. Coral bleaching and mortality in Panama and Ecuador during the 1997-1998 El Nino-Southern Oscillation event: spatial/temporal patterns and comparisons with the 1982-1983 event. Bull. Mar. Sci. 69: 79-109.

Glynn, P.W., B. Riegl, A.M.S. Correa \& I.B. Baums. 2009. Rapid recovery of a coral reefs at Darwin Island, Galapagos Islands. Galapagos Res. 66: 6-13.

Guzman, H.M. 1986. Estructura de la comunidad arrecifal de la Isla del Caño, Costa Rica, y el efecto de perturbaciones naturales severas. Tesis de Maestría, Universidad de Costa Rica, San José, Costa Rica. 179 p.

Guzman, H.M. \& J. Cortés. 1989. Growth of eight species of scleractinian corals in the eastern Pacific (Costa Rica). Bull. Mar. Sci. 44: 1186-1194.

Guzman, H.M. \& J. Cortés. 1992. Cocos Island (Pacifico of Costa Rica) coral reefs after the1982-83 El Niño disturbance. Rev. Biol. Trop. 40: 309-324.

Guzman, H.M. \& J. Cortés. 2001. Changes in reef community structure after fifteen years of natural disturbances in the eastern Pacific (Costa Rica). Bull. Mar. Sci. 69: 133-149.

Guzman, H.M. \& J. Cortés 2007. Reef recovery 20 years after the 1982-1983 El Niño massive mortality. Mar. Biol. 151: 401-411.

Guzman, H.M., J. Cortés, R.H. Richmond \& P.W. Glynn. 1987. Efectos del fenómeno de «El Niño-Oscilación Sureña» 1982-83 en los arrecifes coralinos de la Isla del Caño, Costa Rica. Rev. Biol. Trop. 35: 325-332.

Harborne, A.R., P.G. Renaud, E.H.M. Tyler \& P.J. Mumby. 2009. Reduced density of the herbivorous urchin Diadema antillarum inside a Caribbean marine reserve linked to increased predation pressure by fishes. Coral Reefs 28: 783-791.

Jiménez, C. 1998. Arrecifes y comunidades coralinas de Bahía Culebra, Pacifico Norte de Costa Rica (Golfo 
de Papagayo). Tesis de maestría, Universidad de Costa Rica, San José, Costa Rica. 218 p.

Jiménez, C. 2001. Arrecifes y ambientes coralinos de Bahía Culebra, Pacífico de Costa Rica: aspectos biológicos, económico-recreativos y de manejo. Rev. Biol. Trop. 49 (Supl. 2): 215-231.

Jiménez, C. 2007. Arrecifes coralinos ¿víctimas de los cambios? Ambientico 171: 5-7.

Jiménez, C. \& J. Cortés. 2001. Effects of the 1991-1992 El Niño on scleractinian corals of the Costa Rican central Pacific coast. Rev. Biol. Trop. 49 (Suppl. 2): 239-250.

Jiménez, C.E. \& J. Cortés. 2003. Growth of seven species of scleractinian corals in an upwelling environment of the eastern Pacific (Golfo de Papagayo, Costa Rica). Bull. Mar. Sci. 72: 187-198.

Jiménez, C., J. Cortés, A. León \& E. Ruiz. 2001. Coral bleaching and mortality associated with the1997-98 El Niño in an upwelling environment in the eastern Pacific (Gulf of Papagayo, Costa Rica). Bull. Mar. Sci. 69: 151-169.

Lamberts, A. 1978. Coral growth: alizarin method, p. 523-527. In D. Stoddart \& R. Johannes (eds.). Coral Reefs: Research Methods. UNESCO, Paris.

Lessios, H.A., B.D. Kessing, G.M. Wellington \& A. Graybeal. 1996. Indo-Pacific echinoids in the tropical eastern Pacific. Coral Reefs 15: 133-142.

Macintyre, I.G., P.W. Glynn \& J. Cortés. 1992. Holocene reef history in the eastern Pacific: mainland Costa Rica, Caño Island, Cocos Island, and Galápagos Islands. Proc. $7^{\text {th }}$ Int. Coral Reef Symp., Guam 2: 1174-1184.

Manzello, D.P., J.A. Kleypas, D.A. Budd, C.M. Eakin, P.W. Glynn \& C. Langdon. 2008. Poorly cemented coral reefs of the eastern tropical Pacific: possible insights into reef development in a high- $\mathrm{CO}_{2}$ world. Proc. Nat. Acad. Sci. 105: 10450-10455.

McClanahan, T.R., N.A. Muthinga, A.T. Kamukuru, H. Machado \& R.W. Kiambo. 1999. The effects of marine parks and fishing on coral reefs of northern Tanzania. Biol. Conserv. 89: 161-182.

Morse, D.E.N., N. Hooker, A.N.C. Morse \& R.A. Jensen. 1988. Control of larval metamorphosis and recruitment in sympatric agariciid coral. J. Exp. Mar. Biol. Ecol. 116: 193-217.

Muthiga, N.A. \& T.R. McClanahan. 2007. Ecology of Diadema, p. 205-219. In J.M. Lawrence (ed.). Edible Sea Urchins: Biology and Ecology. Elsevier, Amsterdam, The Netherlands.
Perry, C.T., T. Spencer, \& P.S. Kench. 2008. Carbonate budgets and reef production states: a geomorphic perspective on the ecological phase-shift concept. Coral Reefs 27: 853-866.

Reaka-Kudla M.L., J.S. Feingold, \& P.W. Glynn. 1996. Experimental studies of rapid bioerosion of coral reefs in the Galápagos Islands. Coral Reefs 15: 101-107.

Reyes-Bonilla, H. \& L.E. Calderón-Aguilera. 1999. Population density, distribution and consumption rates of three corallivores at Cabo Pulmo reef, Gulf of California. P.Z.N.S.I.: Mar. Ecol. 20: 347-357.

Scott, P.J.B., M.J. Risk \& J.D. Carriquiry. 1988. El Niño, bioerosion and the survival of east Pacific reefs. Proc. $6^{\text {th }}$ Int. Coral. Reef. Symp., Australia 2: 517-520.

Sonnenholzner, J.I., L.B. Ladah \& K.D. Lafferty. 2009. Cascading effects of fishing on Galapagos rocky reef communities: reanalysis using corrected data. Mar. Ecol. Prog. Ser. 375: 209-218.

Tewfik, A., J.B. Rasmussen \& K.S. McCann. 2005. Anthropogenic enrichment alters a marine benthic food web. Ecol. 86: 2726-2736.

Toro-Farmer, G.A. 1998. Estimación de la intensidad bioerosionadora de los erizos (Echinodermata) en un arrecife coralino de la Isla Gorgona-Pacífico colombiano. Tesis Licenciatura, Facultad de Ciencias, Universidad del Valle, Cali, Colombia. 53 p.

Torrejón-Arellano, N., G. Ramírez-Ortíz, H. Reyes-Bonilla, A.L. Cupul-Magaña \& D. Herrero-Pérezrul. 2008. Community structure of echinoderms in the only pristine area of western Mexico. Gulf of Mexico Sci. 26: 166-167.

Vance, R.R. 1979. Effects of grazing by the urchin, Centrostephanus coronatus, on prey community composition. Ecology 60: 537-546.

Vermeij, M.J.A., M.L. Dayler, S.M. Walsh, M.K. Donovan, \& C.M. Smith. 2010. The effects of trophic interactions and spatial competition on algal community composition on Hawaiian coral reefs. Mar. Ecol. 31: 291-299.

Veron, J.E.N., O. Hoegh-Gulberg, T.M. Lenton, J.M. Lough, D.O. Obura, P. Pearce-Kelly, C.R.C. Sheppard, M. Spalding, M.G. Stafford-Smith \& A.D. Rogers. 2009. The coral reef crisis: The critical importance of $<350 \mathrm{ppm} \mathrm{CO}_{2}$. Mar. Poll. Bull. 58: 1428-1436.

Weinberg, S. 1981. A comparison of coral reef survey methods. Bijdr. Dierk. 51: 199-218. 